\title{
Blood volume and albumin transudation in critically ill COVID-19 patients
}

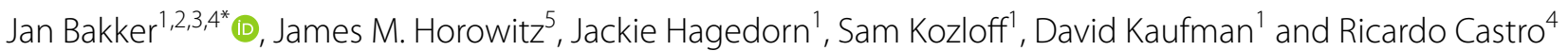

\section{To the Editor:}

The SARS-CoV-2 infection (COVID-19) in critically ill patients presents as a viral pneumonia and inflammation affecting the endothelium [1] with unclear consequences for fluid leakage to the extravascular space. Nevertheless, the adapted Surviving Sepsis Guidelines advocate a conservative fluid strategy [2]. By using a radiolabeled albumin tracer, the total blood volume (TBV), red blood cell volume (RBCV), plasma volume (PV), and the albumin transudation rate (ATR) can be measured [3]. In six mechanically ventilated patients (admitted March/April 2020), the TBV was measured [4] as advanced hemodynamic monitoring was not used, and the volume status was unclear. The volumes measured were corrected for the ideal body weight of a corresponding healthy individual, and deviations were calculated. The results of only the TBV, RBCV, and PV were communicated with the treatment team.

We retrospectively analyzed these data together with the ATR. Albumin transudation rate is presented as a numeric value with $0.0025(0.25 \% / \mathrm{min}$ exiting the circulation) serving as the normal reference threshold. We report absolute variation (values at admission minus value at day of measurement for each case), and dayindexed values, calculated by dividing the absolute variation by the number of days in the ICU. We performed univariate regression between albumin transudation and variables of interest. In the multivariate regression, we tested variables that showed statistical significance in

${ }^{*}$ Correspondence: jan.bakker@nyulangone.org

${ }^{1}$ Division of Pulmonary, Critical Care, and Sleep Medicine, New York University School of Medicine, New York, NY, USA

Full list of author information is available at the end of the article the univariate analysis and other that did not reach the significance threshold but had clinical relevance. Data are expressed as mean \pm 1 standard deviation unless otherwise indicated. A $p$ value of equal or less than 0.05 was considered significant. None of the patients was diagnosed with a secondary infection the days before the measurement. Age of the patients was $66 \pm 11$ year with a mean weight of $86.3 \pm 15.7 \mathrm{~kg}$. Only one patient did not have any comorbidity on admission where the most frequent comorbidity was diabetes (four patients, two in combination with hypertension). Four patients died, all of whom developed complete renal failure. At the time of measurement, all patients had stable hemodynamics only one patient received vasopressor support (norepinephrine $0.42 \mathrm{mcg} / \mathrm{kg} / \mathrm{min}$ ). Results are shown in Table 1 . Three of the four clinically hypervolemic patients (assessed by fluid balance and extend of peripheral edema), TBV showed a decreased value from ideal body weight. The median ATR was $0.46 \% / \mathrm{min}$ (range 0.12 0.82 ). There was a strong linear relationship between the day of admission and ATR $\left(\mathrm{R}^{2}=0.99, P<0.0001\right)$ and a curve linear relationship with the deviation of the TBV $\left(\mathrm{R}^{2}=0.63, p<0.03\right)($ Fig. 1$)$.

In an exploratory multivariate regression model, we found TBV deviation $(p=0.022)$ and net fluid balance since admission $(p=0.018)$ and CRP at day of measurement $(p=0.043)$ to explain $99 \%$ of the variation in ATR.

Although endothelial damage is believed to be an important part of COVID-19 and related to the severity of illness [5] and aggregates of red and white blood cells in the microcirculation have been reported [6], extensive capillary leakage has not been reported before. As a nosocomial bacterial infection had not been confirmed in any of the patients, the severity of COVID-19 and the original author(s) and the source, provide a link to the Creative Commons licence, and indicate if changes were made. The images or other third party material in this article are included in the article's Creative Commons licence, unless indicated otherwise in a credit line to the material. If material is not included in the article's Creative Commons licence and your intended use is not permitted by statutory regulation or exceeds the permitted use, you will need to obtain permission directly from the copyright holder. To view a copy of this licence, visit http://creativecommons.org/licenses/by/4.0/. The Creative Commons Public Domain Dedication waiver (http://creativeco mmons.org/publicdomain/zero/1.0/) applies to the data made available in this article, unless otherwise stated in a credit line to the data. 
Table 1 Characteristics of individual patients at day of blood volume measurement

\begin{tabular}{|c|c|c|c|c|c|c|c|}
\hline Parameter at time of measurement & $\begin{array}{l}\text { Pat } 1 \\
\# S\end{array}$ & $\begin{array}{l}\text { Pat } 2 \\
\% \# N S\end{array}$ & $\begin{array}{l}\text { Pat } 3 \\
\text { NS }\end{array}$ & $\begin{array}{l}\text { Pat } 4 \\
\text { NS }\end{array}$ & $\begin{array}{l}\text { Pat } 5 \\
\text { \#NS }\end{array}$ & $\begin{array}{l}\text { Pat } 6 \\
\text { S }\end{array}$ & $\begin{array}{l}\text { Mean } \pm \text { SD } \\
\text { Median IQR }\end{array}$ \\
\hline ICU Admission & $\begin{array}{l}\text { March } \\
2020\end{array}$ & $\begin{array}{l}\text { March } \\
2020\end{array}$ & $\begin{array}{l}\text { April } \\
2020\end{array}$ & $\begin{array}{l}\text { April } \\
2020\end{array}$ & $\begin{array}{l}\text { April } \\
2020\end{array}$ & $\begin{array}{l}\text { April } \\
2020\end{array}$ & \\
\hline Day of ICU admission at measurement & 14 & 20 & 11 & 13 & 7 & 2 & \\
\hline Age|male/female & $70 \mid \mathrm{M}$ & $69 \mid M$ & $49 \mid M$ & $62 \mid M$ & $66 \mid \mathrm{F}$ & $81 \mid \mathrm{M}$ & $\begin{array}{l}66 \pm 11 \\
68(59-73)\end{array}$ \\
\hline Height (cm) & 1.75 & 1.73 & 1.65 & 1.73 & 1.58 & 1.52 & $166 \pm 0.09 \mid 1.69(1.57-1.74)$ \\
\hline Weight (kg) & 76.2 & 78.0 & 77.8 & 67.8 & 93.9 & 61.8 & $75.9 \pm 10.9 \mid 77.0(66.3-82.0)$ \\
\hline Ideal body weight (kg) & 70.0 & 69.0 & 61.0 & 69.0 & 51 & 50.0 & $61.7 \pm 9.2 \mid 65.0(50.8-69.3)$ \\
\hline Heart rate (b/min) & 95 & 104 & 97 & 69 & 112 & 72 & $\begin{array}{l}92 \pm 17 \\
96(71-106)\end{array}$ \\
\hline Systolic arterial pressure $(\mathrm{mmHg})$ & 137 & 72 & 97 & 94 & 146 & 96 & $\begin{array}{l}107 \pm 28 \\
97(89-138)\end{array}$ \\
\hline Diastolic arterial pressure $(\mathrm{mmHg})$ & 56 & 38 & 66 & 48 & 52 & 42 & $\begin{array}{l}50 \pm 10 \\
50(41-59)\end{array}$ \\
\hline Mean arterial pressure $(\mathrm{mm} \mathrm{Hg})$ & 79 & 50 & 76 & 66 & 75 & 58 & $\begin{array}{l}67 \pm 11 \\
71(56-77)\end{array}$ \\
\hline Lactate (mmol/L) & 1.5 & 1.6 & 1.3 & 2.5 & 1.8 & 1.4 & $\begin{array}{l}1.7 \pm 0.4 \\
1.6(1.4-2.0)\end{array}$ \\
\hline$C$ reactive protein at measurement $(\mathrm{mg} / \mathrm{L})$ & 3 & 239 & 409 & 282 & 263 & 50 & $\begin{array}{l}208 \pm 153 \\
251(38-313)\end{array}$ \\
\hline Inspired oxygen fraction & 0.4 & 0.8 & 0.7 & 1 & 0.8 & 0.4 & $\begin{array}{l}0.68 \pm 0.24 \\
0.75(0.4-0.9)\end{array}$ \\
\hline Pulse oximetry (\%) & 97 & 95 & 96 & 95 & 91 & 96 & $\begin{array}{l}95 \pm 2 \\
96(94-97)\end{array}$ \\
\hline Net fluid balance day before measurement $(\mathrm{L})$ & -0.9 & 1.2 & 1.3 & -0.3 & -0.9 & 3.0 & $\begin{array}{l}0.6 \pm 1.5 \\
0.45(-0.9 \text { to } 1.7)\end{array}$ \\
\hline Fluids IN day before measurement $(\mathrm{L})$ & 3.6 & 2.1 & 2.6 & 1.7 & 3.1 & 3.2 & $\begin{array}{l}2.7 \pm 0.7 \\
2.9(2.0-3.3)\end{array}$ \\
\hline Urine output day before measurement $(\mathrm{L})$ & 4.5 & 0.7 & 0.8 & 2.7 & 1.8 & 0.7 & $\begin{array}{l}1.9 \pm 1.5 \\
1.3(0.7-3.2)\end{array}$ \\
\hline Fluids in since admission $(\mathrm{L})$ & 36.8 & 41 & 17.2 & 19.8 & 15.4 & 3.8 & $\begin{array}{l}22.3 \pm 14.0 \\
18.5(12.5-37.9)\end{array}$ \\
\hline Net fluid balance since admission (L) & 8.2 & 10 & 5.9 & 3.0 & 0.3 & 4.0 & $\begin{array}{l}5.2 \pm 3.5 \\
5.0(2.3-8.7)\end{array}$ \\
\hline Clinical assessment of volume status & Hyper & Hyper & $\mathrm{Eu}$ & Hyper & Hyper & Нyро & \\
\hline Total blood volume (mL) & 4200 & 4290 & 5360 & 3990 & 4870 & 4552 & $\begin{array}{l}4544 \pm 502 \\
4421(4223-4791)\end{array}$ \\
\hline Red cell volume (mL) & 1215 & 935 & 1391 & 841 & 1220 & 1370 & $\begin{array}{l}1162 \pm 227 \\
1218(1005-1333)\end{array}$ \\
\hline Plasma volume $(\mathrm{mL})$ & 2985 & 3355 & 3969 & 3149 & 3650 & 3182 & $\begin{array}{l}3382 \pm 366 \\
3269(3157-3576)\end{array}$ \\
\hline Total blood volume dev (\%) & -16.6 & -17.3 & -15.2 & -18.9 & +3.3 & +17.2 & $\begin{array}{l}-7.9 \pm 14.8 \\
-15.9(-17.7 \text { to } 6.8)\end{array}$ \\
\hline Red cell volume dev (\%) & $-41 \%$ & $-56 \%$ & $-26 \%$ & $-58 \%$ & $-28 \%$ & $-13 \%$ & $-34(-56$ to -23$)$ \\
\hline Plasma volume dev (\%) & $-0 \%$ & $9 \%$ & $44 \%$ & $8 \%$ & $21 \%$ & $38 \%$ & $15 \%(6-39)$ \\
\hline Albumin transudation rate $(\% / \mathrm{min})$ & 0.58 & 0.82 & 0.43 & 0.49 & 0.24 & 0.12 & $\begin{array}{l}0.45 \pm 0.25 \\
0.46(0.21-0.64)\end{array}$ \\
\hline
\end{tabular}

Mean $\pm S D$ and median (IQR 25, 75)

$\%=$ being treated with norepinephrine, \# = being treated with diuretic, $\mathrm{S}=$ survivor, NS= non-survivor

Hyper: hypervolemia, Eu: euvolemia, Hypo: hypovolemia. Total blood volume deviation: absolute and relative deviation of the expected total blood volume of a healthy individual 


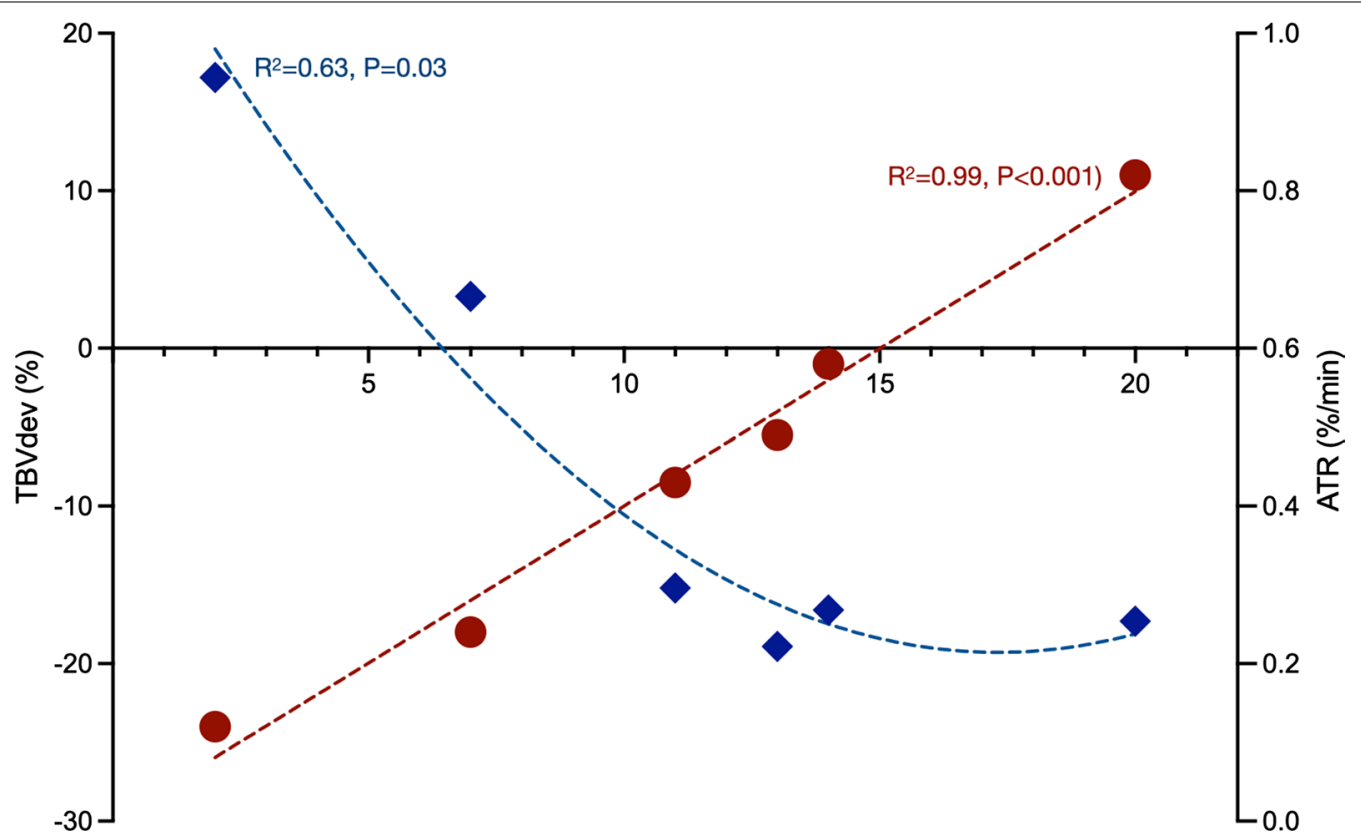

Fig. 1 Relationship between the albumin transudation rate (ATR) and the deviation of the total blood volume from ideal (TBV deviation)

systemic inflammatory response could be a more likely explanation. This vascular leakage could result in tissue edema and ultimately organ dysfunction as seen in these patients. Although this may suggest a role for the use of specific fluids (such as colloids) in this disease, our current data do not allow such recommendation. Given the only one-time measurement results should be interpreted with caution. This study could be seen as a unique exploratory study in COVID-19 patients. We have therefore initiated a multicenter prospective study to improve our understanding of blood volume and vascular leakage in critically ill COVID-19 patients (NCT04517695).

\section{Acknowledgements}

Not applicable.

\section{Authors' contributions}

$J \mathrm{~B}$ contributed to acquisition of data, the writing of the manuscript, analysis of the data, and construction of the figure and table. JMH, JH, and DK contributed to the writing of the manuscript. SK contributed to acquisition of data and the writing of the manuscript. RC contributed to the writing of the manuscript, analysis of the data, and the construction of the figure and table. All authors read and approved the final manuscript.

\section{Funding}

The study was not supported. The prospective study that has started is supported by the Daxor Company that performs the analysis of the samples for participating centers.

\section{Availability of data and materials}

Supporting data are available upon request to the corresponding author 3 months after publication.

\section{Declarations}

Ethics approval and consent to participate

As the measurements of blood volume were done on clinical indication and the retrospective analysis of the data did not contain patient-specific information, the IRB decided that this study did not require additional informed consent. The communication with the IRB on this topic is included as a supplement.

\section{Consent for publication}

Not applicable.

\section{Competing interests}

JB has received consulting grants from Daxor Company. Other authors have no competing interest to declare.

\section{Author details}

${ }^{1}$ Division of Pulmonary, Critical Care, and Sleep Medicine, New York University School of Medicine, New York, NY, USA. ${ }^{2}$ Division of Pulmonary, Allergy, and Critical Care Medicine, Columbia University College of Physicians and Surgeons, New York, NY, USA. ${ }^{3}$ Department of Intensive Care Adults, Erasmus MC University Medical Center, Rotterdam, Netherlands. ${ }^{4}$ Department of Intensive Care, Pontificia Universidad Católica de Chile, Santiago, Chile. ${ }^{5}$ Division of Cardiology, New York University School of Medicine, New York, NY, USA.

Received: 30 March 2021 Accepted: 21 July 2021

Published online: 31 July 2021

\section{References}

1. Pons S, Fodil S, Azoulay E, Zafrani L. The vascular endothelium: the cornerstone of organ dysfunction in severe SARS-CoV-2infection. Crit Care. 2020;24(1):353.

2. Alhazzani W, Moller MH, Arabi YM, Loeb M, Gong MN, Fan E, Oczkowski S, Levy MM, Derde L, Dzierba A, et al. Surviving sepsis campaign: guidelines on the management of critically ill adults with coronavirus disease 2019 (COVID-19). Crit Care Med. 2020;48(6):e440-69. 
3. Feldschuh J, Enson Y. Prediction of the normal blood volume. Relation of blood volume to body habitus. Circulation. 1977;56(4 Pt 1):605-12.

4. Manzone TA, Dam HQ, Soltis D, Sagar W. Blood volume analysis: a new technique and new clinical interest reinvigorate a classic study. J Nucl Med Technol. 2007;35(2):55-63 (quiz 77, 79).

5. Fraser DD, Patterson EK, Slessarev M, Gill SE, Martin C, Daley M, Miller MR, Patel MA, Dos Santos CC, Bosma KJ, et al. Endothelial injury and glycocalyx degradation in critically ill coronavirus disease 2019 patients: implications for microvascular platelet aggregation. Crit Care Explor. 2020;2(9):e0194.
6. Favaron E, Ince C, Hilty MP, Ergin B, van der Zee P, Uz Z, Wendel Garcia PD, Hofmaenner DA, Acevedo CT, van Boven WJ et al. Capillary leukocytes, microaggregates, and the response to hypoxemia in the microcirculation of coronavirus disease 2019 patients. Crit Care Med 2021;49:661-70.

\section{Publisher's Note}

Springer Nature remains neutral with regard to jurisdictional claims in published maps and institutional affiliations.
Ready to submit your research? Choose BMC and benefit from:

- fast, convenient online submission

- thorough peer review by experienced researchers in your field

- rapid publication on acceptance

- support for research data, including large and complex data types

- gold Open Access which fosters wider collaboration and increased citations

- maximum visibility for your research: over 100M website views per year

At BMC, research is always in progress.

Learn more biomedcentral.com/submissions 